\title{
Modifikasi Solar Water Destiler Dengan Menambahkan Unit Pemanas Berenergi Solar Cell
}

\section{Modification Of The Solar Water Destiler By Adding A Solar Cell Energy Heating Unit}

\author{
Iskandar Zulkarnain, Kelik Istanto \\ Jurusan Teknologi Pertanian, Politeknik Negeri Lampung, \\ Jl. Soekarno Hatta No.10 Bandar Lampung, 35144 \\ "E-mail : iskandar160575@polinela.ac.id
}

\begin{abstract}
Increasing the heat energy in the evaporator box from the Water Solar Destiler, by adding a wire heater aims to increase the heat energy in the evaporator box so that it will speed up the evaporation process in the evaporator box. The more liquid that is broken down due to heat energy into water vapor, the more discharge will be produced. Based on the results of the observations made, the addition of a wire heater in the evaporator city with AC electricity generated by solar panels, increased the purified water by $248.78 \%$, from 1745 $\mathrm{ml}$ to $4341 \mathrm{ml}$, with the thickness of the water being purified as thick as $1 \mathrm{~cm}$ which was dried in the sun. for 10 hours starting from 07.00 WIB to 17.00 WIB.
\end{abstract}

Keywords: fresh water, solar panel, water solar distaler

Naskah ini diterima pada tanggal 19 Juni 2020, direvisi pada tanggal 3 Juli 2020 dan disetujui untuk diterbitkan pada tanggal 15 Agustus 2020

\section{PENDAHULUAN}

Solar Water Destiler, adalah sebuah teknologi alternatif yang murah dan ramah lingkungan, yang dapat diterapkan untuk untuk menghasilkan air bersih. Proses yang selanjutnya di kenal dengan "penyulingan surya" ini, bekerja berdasarkan mekanisme siklus air alami, yaitu memanfaatkan energi panas matahari untuk memecah molekul air sehingga terpisah dari zat-zat yang terlarut didalamnya sampai yang dikemudian menjadi uap. Kejadian selanjutnya, pada suatu fasa, uap air akan terakumulasi, menjadi jenuh dan terkondensasi, sehingga berubah menjadi titiktitik air kembali yang sudah terpisah dari partikel-partikel terlarut didalamnya.

Zulkarnain, (2016), mendesain alat pemurni air laut menjadi air tawar dengan mengkombinasikan kotak penguap dengan kolektor panas cermin cekung dan kotak pengembun untuk memurnikan air laut. Pada kegiatan penelitaian tersebut disimpulkan bahwa pada ketebalan air baku (air laut) setinggi $1 \mathrm{~cm}$ di dalam kotak penguap yang dijemur dan dipanaskan dengan cermin cekung selama 10 jam mulai pukul 07.00-17.00 WIB, menghasilkan debit air tawar sebesar $1718 \mathrm{ml}$. Nilai debit yang dihasilkan ini sesungguhnya masih tidak signifikan secara kuantitas, jika dibandingkan dengan waktu penjemuran dan pemanasan yang dilakukan. Keterbatasan hasil debit ini tentu saja sangat dipengaruhi oleh kondisi penyinaran panas matahari, karena dalam kegiatan 
yang dilakukan, penjemuran dan pemanasan kotak penguap selama 10 jam ini, intensitas energi cahaya matahari tidak dapat di kontrol untuk memanaskan kotak penguap secara terus-menerus.

Apabila pemanasan pada kotak penguap dengan menggunakan energi cahaya matahari dapat dilakukan secara kontinyu, tidak tergantung pada kondisi cuaca yang mendung atau tertutup awan, maka diduga alat yang didesain akan menghasilkan jumlah debit yang cukup signifikan.

Energi cahaya matahari ini dapat dikonversikan menjadi bentuk lain yang dapat dimanfaatkan oleh kita sebagai manusia, dengan rekayasa teknologi photovoltaics (PV), teknologi photothermal, dan dan teknologi fotokimia (Xing, J., 2017)

Di bagian lain, Zulkarnain, (2016), memberikan saran untuk melakukan modifikasi alat dengan menambahkan unit pemanas (wire heater) berenergi solar cell sebagai upaya untuk membuat kotak pemanas menerima energi panas yang terus-menerus. Dengan modiifikasi ini diharapkan akan memberikan kotak penguap akan secara mendapat energi panas yang merata dan tidak terputus.

Penggunaan panel surya sebagai piranti semiconductor, memungkinkan untuk mengubah energi matahari secara langsung menjadi energi listrik DC (arus searah) dengan menggunakan kristal Si (silicon) yang tipis (Dewi, A.Y., Antonov, 2013).

Energi listrik DC (arus searah) yang dihasilkan panel surya kemudian dapat disimpan pada komponen ACCU/AKI/Battery, digunakkan dan di recharge. Pada kebutuhan sumber energi listrik dengan jenis arus yang berbeda (AC/Arus bolak-bali), energi listrik DC pada battery selanjutnya dapat diubah menjadi energi listrik AC (arus bolak-balik) dengan menggunakan sebuah alat yang disebut power inverter.

Dengan adanya Energi listrik AC (arus bolak-balik) yang dihasilkan kemudian akan dihubungkan dengan unit pemanas (wire heater) yang telah dipasang pada kotak penguap, sehingga proses pemanasan didalam kotak pemanas akan terus berlangsung secara terus menerus, walau pada kondisi intensitas cahaya matahari yang relatif rendah.

Berdasarkan uraian diatas, maka dilakukan pengamatan terhadap kinerja alat yang di modifikasi dengan menambahkan unit unit pemanas (wire heater) yang dihubungkan pada energi listrik AC hasil modifikasi arus DC yang dihasilkan oleh panel surya.

Tujuan dari penelitian ini adalah melakukan modifikasi kotak penguap dengan penambahan wire heater menggunakan energi sel surya untuk mengamati perubahan jumlah debit air hasil destilasi yang dihasilkan.

\section{METODE PENELITIAN}

Penelitian ini menggunakan jenis penelitian eksperimen dengan menggunakan alat yang dirancang pada kegiatan penelitian sebelumnya. Rancang alat yang dihasilkan pada penelitian yang dilakukan sebelumnya yaitu menggunakan kotak penguap dan kolektor panas cermin cekung, kemudian dilakukan modifikasi dengan menambahkan unit pemanas (wire heater) bersumber 108 Volume 12, Nomor 2| Agustus 2020: 65-126 
energi dari panel surya. Dengan penambahan unit pemanas ini, diharapkan rancangan alat sebelumnya dapat bekerja lebih optimal untuk menghasilkan debit air bersih hasil proses pemurnian. Secara garis besar diagram alir pelaksanaan penelitian yang akan dilakukan seperti yang disajikan pada Gambar 1.

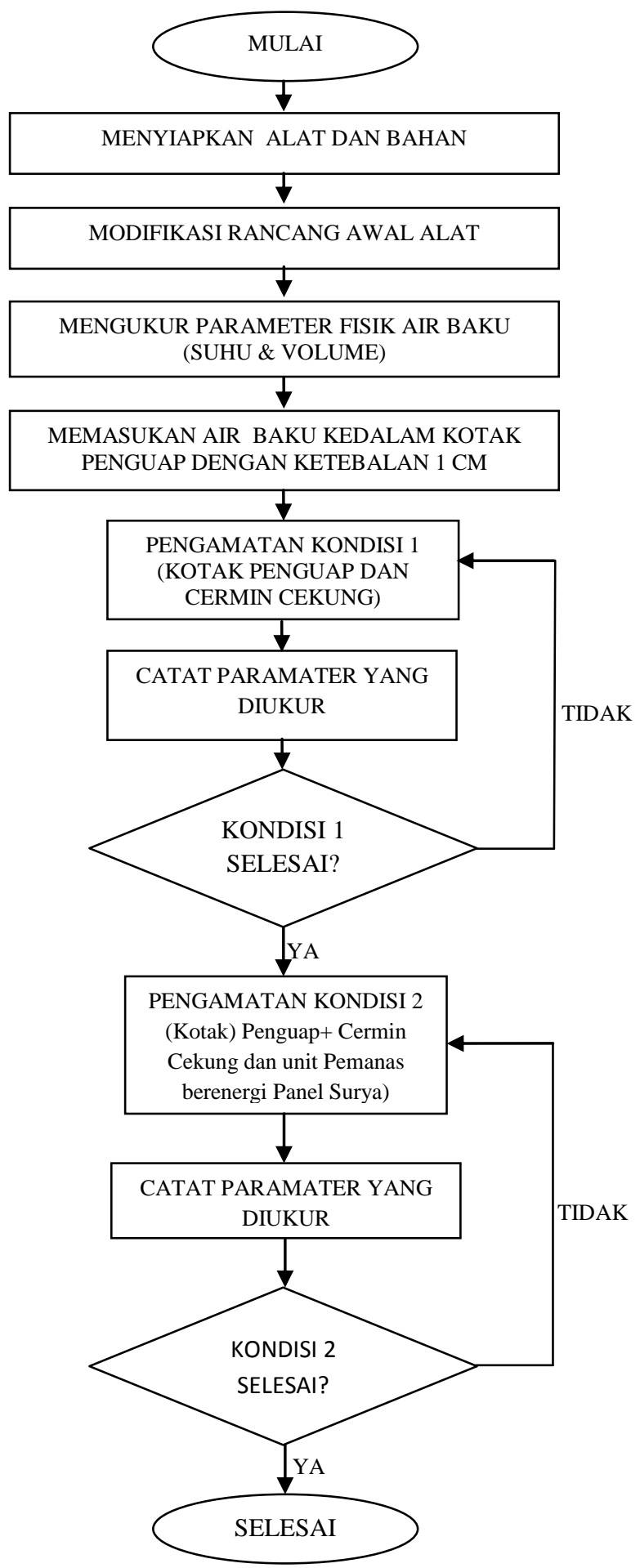

Gambar 1. Diagram Alir Pelaksanaan Penelitian 


\section{BAHAN DAN ALAT}

Bahan dan peralatan yang digunakan dalam kegiatan penelitian ini terdiri dari air baku berasal dari sungai dengan kondisi keruh, satu set alat water solat destiler (kotak penguap + kolektor panas cermin cekung), Panel Surya, Solar Charge Controler, Battery 12V/6A, DC to AC Power Inverter.

\section{RANCANG MODIFIKASI ALAT}

Rancangan modifikasi alat alat terdiri dari 2 bagian utama, yaitu alat utama yang sudah pernah didesain berupa set water solar distaler dan bagian modidikasi terdiri dari wire heater dengan sumber arus dari panel surya. Adapun secara ilustrasi gambar rancangan alat seperti yang ditunjukan pada Gambar 2.

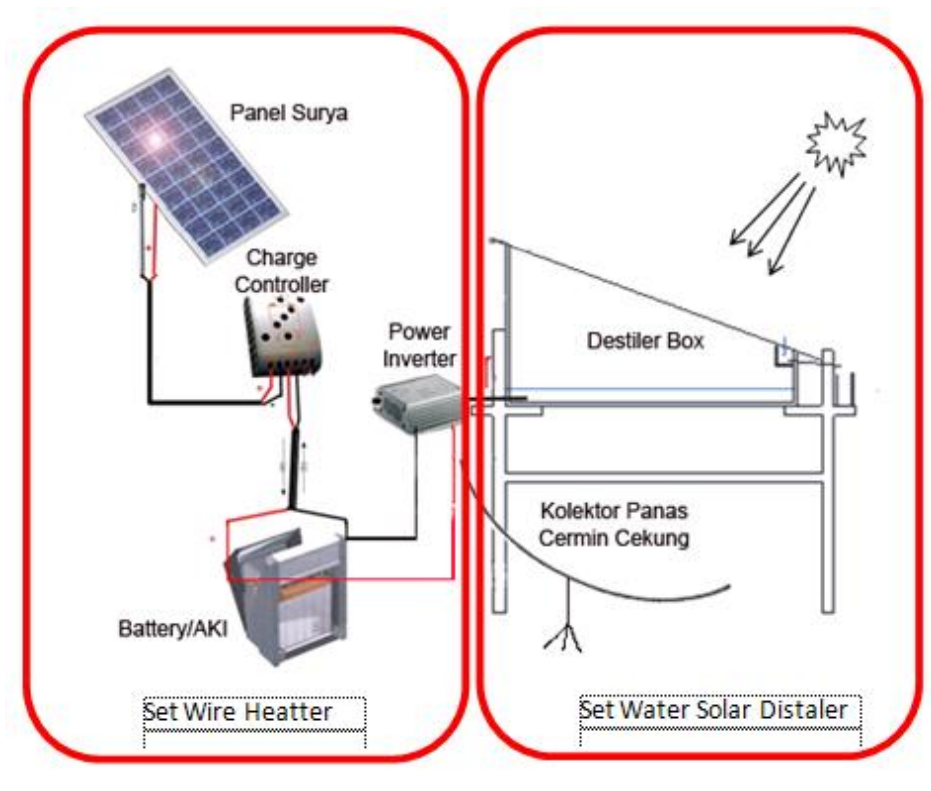

Gambar 2. Rancangan Modifikasi Alat

\section{KONSEP KERJA RANCANGAN ALAT}

Rancangan modifikasi dititik tekankan pada upaya peningkatan energi panas yang diterima oleh kotak penguap, sehingga air baku yang akan dimurnikan akan cepat memanas dan akhirnya menguap. Alat water solar destiler yang dihasilkan dari penelitian pada tahap pertama (berupa 1 set water solar distaler) kemudian di lakukan penambahan wire heater pada bagian dalam kotak penguap yang berenergi listrik AC. Sumber daya listrik yang digunakan adalah berasal dari panel surya 50 WP yang dimodifikasi sedemikian rupa sehingga keluarannya berupa arus listrik bolakbalik (AC/Alternating Current).

Fungsi water heater yang dipasang pada kotak penguap adalah untuk meningkatkan proses pemanasan air baku didalam kotak penguap. Pemilihan wire heater dilakukan sedemikian rupa 
dengan mempertimbangkan keamanan dari kejutan listrik atau (setrum) yang mungkin dapat terjadi jika dipilih jenis yang salah.

\section{PARAMETER YANG DIUKUR}

Parameter yang diukur pada penelitian ini meliputi: debit air hasil filtrasi

\section{PROSEDUR PELAKSANAAN PENELITIAN}

Prosedur penelitian dilakukan dengan tahapan sebagai berikut:

a. Mempersiapkan alat dan bahan yang akan digunakan

b. Melakukan modifikasi bak penguap dengan memasang unit pemanas (wire heater).

c. Menyiapkan panel surya, Solar Charge Controler, Baterry/Aki/Acuu, power inverter.

d. Menghubungkan rangkaian panel surya ke Solar Charge Controler, kemudian menghubungkannya ke battery/aki/accu, agar arus listri DC dari panel surya dapat disimpan di dalam Aki/acuu

e. Mengubah arus DC didalam unit battery/aki/accu menjadi arus Ac dengan menghubungkan baterry ke unit power inverter.

f. Menghubungkan unit pemanas yang sudah terpasang pada kotak penguap ke sumber listrik AC dari power inverter, pada posisi off.

g. Menyiapkan air baku berupa tawar keruh yang akan dijernihkan.

h. Memasukan air baku yang akan dimurnikan, dengan beberapa variasi ketinggian yaitu $1 \mathrm{~cm}$ ke dalam kotak penguap.

i. Alat yang sudah berisi air yang akan dimurnikan tersebut dijemur di bawah sinar matahari secara langsung, berikut juga unit panel surya.

j. Memposisikan ON power inverter, sehingga unit pemanas (wire heater) bekerja .

k. Mencatat temperatur air pada kotak penampung setiap 1 jam sekali.

1. Mencatat debit air yang dihasilkan setiap 1 jam. Pencatatan debit hasil destilasi dilakukan selama kondisi power inverter masih dapat menghasilkan arus listrik.

m. Menampung air hasil destilasi akhir pada sebuah wadah yang diberikan ukuran ketinggian pada salah satu bagiannnya.

\section{HASIL DAN PEMBAHASAN}

Rancangan modifikasi alat tersusun atas 2 bagian yaitu:

a. 1 set water solar distaler (terdiri dari kotak penguap dan cermin cekung)

b. 1 set water heater yang terdiri dari wire heater, panel surya dan accu 12 volt

Adapun gambar dari masing-masing alat sebagaimana berikut: 

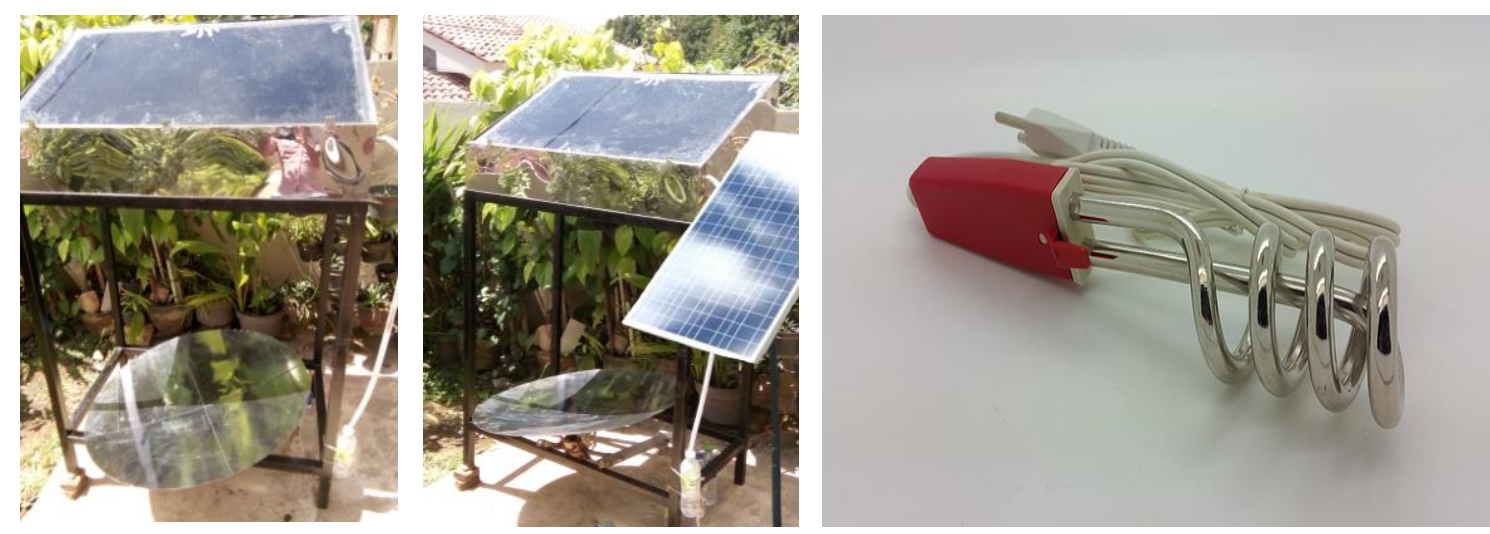

Gambar 3. Set Alat Modifikasi

\section{UJI AWAL}

Uji awal modifikasi alat adalah dengan menguji apakah wire heater bekerja dengan tingkat keamanan yang baik. Indikasi keamanan alat adalah tidak terjadinya potensi kesetrum atau tersengat arus listrik bagi operator/pengguna alat ini. Tahapan uji berupa memberikan arus listrik AC pada wire heater yang terpasang pada kotak penguap. Setelah wire heater tersambung arus listrik AC, kemudian di tes dengan TESTPEN apakah ada arus listrik yang mengalir pada air baku didalam kotak penguap. Hasil uji awal performa modifikasi alat, bahwa air didalam kotak penguap cepat memanas (dalam tempo 5 menit sudah memanas) dan tidak ada aliran arus listrik yang berpotensi mengakibatkan seseorang keseterum.

\section{KONDISI PENGAMATAN}

Pengamatan dilakukan dengan membandingkan paremeter ukur dari hasil pemurnian alat menggunakan alat water solar destiler menggunakan pemanasan eksternal kolektor cermin cekung dengan water solar destiler yang menggunakan kolektor cermin cekung ditambah dengan penggunaan wire heater. Penjelasan terhadap kondisi pengamatan disajikan sebagai berikut:

KONDISI A: Parameter yang diamati meliputi suhu udara $(\mathrm{Tu})$, Temperatur Bawah Bak (Tbb), Temperatur Dinding Bak (Tdb), Temperatur Kaca Penutup (Tkc), Volume air destilasi yang dihasilkan (Vd), Suhu Air Hasil yang dihasilkan (Ta) untuk kondisi ketinggian air di dalam baik penguapan setebal $1 \mathrm{~cm}$, menggunakan penambahan kolektor panas cermin cekung.

KONDISI B: Parameter yang diamati meliputi suhu udara (Tu), Temperatur Bawah Bak (Tbb), Temperatur Dinding Bak (Tdb), Temperatur Kaca Penutup (Tkc), Volume air destilasi yang dihasilkan (Vd), Suhu Air Hasil yang dihasilkan (Ta) untuk kondisi ketinggian air di dalam baik penguapan setebal $1 \mathrm{~cm}$, menggunakan penambahan kolektor panas cermin cekung ditambah dengan pengaktifan wire heater. 


\section{DATA PENGAMATAN}

Hasil pengamatan pada KONDISI A, adalah dengan mengamati parameter suhu udara (Tu), Temperatur Bawah Bak (Tbb), Temperatur Dinding Bak (Tdb), Temperatur Kaca Penutup (Tkc), Suhu Air Hasil yang dihasilkan (Ta), Volume air hasil pemurnian pada ketebalan air di dalam bak penguap setinggi $1 \mathrm{~cm}$, tanpa mengaktifkan wire heater. Sehingga pemanasan hanya berasal dari sinar matahari langsung dan pemanasan dengan menggunakan kolektor panas kondisi A pengamatan ini disajikan pada Tabel 1 dan Gambar 4.

Tabel 1. Data Pengamatan Suhu Dan Volume Pada Kondisi A

\begin{tabular}{|c|c|c|c|c|c|c|}
\hline \multirow[t]{2}{*}{ No } & \multirow{2}{*}{$\begin{array}{c}\text { Waktu } \\
\text { Pengamatan }\end{array}$} & \multicolumn{4}{|c|}{ Temperatur $\left({ }^{\circ} \mathrm{C}\right)$ Pada } & \multirow{2}{*}{$\begin{array}{l}\text { Volume } \\
\text { (ml) }\end{array}$} \\
\hline & & Udara & $\begin{array}{l}\text { Dinding } \\
\text { Bak }\end{array}$ & $\begin{array}{c}\text { Bawah } \\
\text { Bak }\end{array}$ & Kaca & \\
\hline 1 & 07.00 & 22 & 22,1 & 22,3 & 22,3 & 0 \\
\hline 2 & 08.00 & 25 & 22,6 & 24,3 & 23,6 & 12 \\
\hline 3 & 09.00 & 30 & 28,6 & 30,2 & 29,8 & 55 \\
\hline 4 & 10.00 & 34 & 38,9 & 43,8 & 38,1 & 94 \\
\hline 5 & 11.00 & 37 & 50,2 & 57,6 & 53,6 & 320 \\
\hline 6 & 12.00 & 37 & 61,4 & 73,2 & 68,6 & 395 \\
\hline 7 & 13.00 & 36 & 53,3 & 61,6 & 58.6 & 340 \\
\hline 8 & 14.00 & 38 & 47,3 & 50,2 & 48.1 & 300 \\
\hline 9 & 15.00 & 30 & 29,5 & 31,5 & 28.4 & 150 \\
\hline 10 & 16.00 & 26 & 27,7 & 28.7 & 26.7 & 56 \\
\hline 11 & 17.00 & 24 & 25,9 & 26,7 & 26.1 & 23 \\
\hline \multicolumn{6}{|c|}{ TOTAL } & 1745 \\
\hline
\end{tabular}

(Sumber: Hasil Pengamatan, 2017)

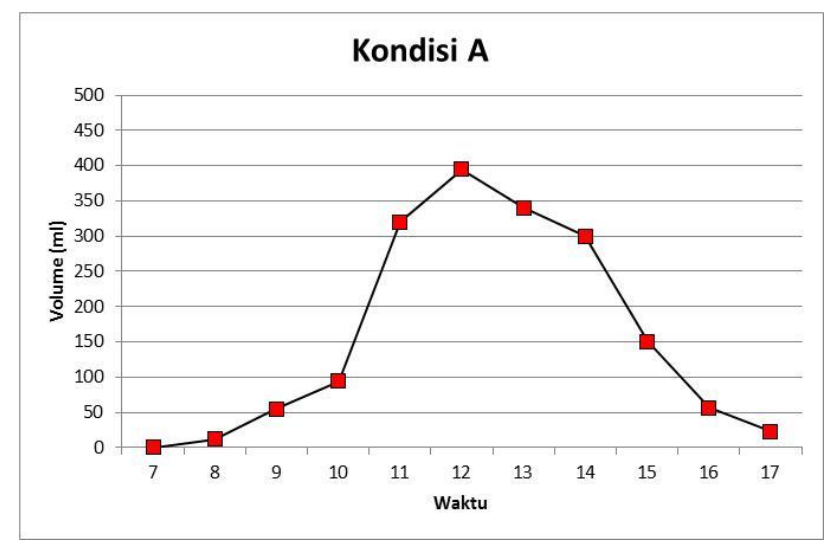

Gambar 4. Grafik Volume Hasil Pemurnian Terhadap Waktu (Kondisi A)

Hasil pengamatan pada KONDISI B, adalah dengan mengamati parameter suhu udara (Tu), Temperatur Bawah Bak (Tbb), Temperatur Dinding Bak (Tdb), Temperatur Kaca Penutup (Tkc), Suhu Air Hasil yang dihasilkan (Ta) dan Volume air hasil pemurnian air hasil pemurnian pada ketebalan air di dalam bak penguap setinggi $1 \mathrm{~cm}$, dengan mengaktifkan wire heater. Hasil pengamatan ini disajikan pada Tabel 2 dan Gambar 5. 
Tabel 2. Data Pengamatan Suhu Dan Volume Pada Kondisi B

\begin{tabular}{ccccccc}
\hline No & $\begin{array}{c}\text { Waktu } \\
\text { Pengamatan }\end{array}$ & Udara & $\begin{array}{c}\text { Dinding } \\
\text { Bak }\end{array}$ & $\begin{array}{c}\text { Bawah } \\
\text { Bak }\end{array}$ & Kaca & $\begin{array}{c}\text { Volume } \\
(\mathbf{m l})\end{array}$ \\
\hline 1 & 07.00 & 23 & 23,4 & 22,3 & 22,9 & 0 \\
\hline 2 & 08.00 & 26 & 25,2 & 48,3 & 24,1 & 150 \\
\hline 3 & 09.00 & 28 & 27,5 & 50,2 & 30,6 & 272 \\
\hline 4 & 10.00 & 33 & 36,9 & 58,3 & 35,7 & 334 \\
\hline 5 & 11.00 & 36 & 50,7 & 62,6 & 55,4 & 521 \\
\hline 6 & 12.00 & 36 & 71,6 & 82,2 & 61,2 & 665 \\
\hline 7 & 13.00 & 34 & 57,4 & 85,6 & 53.8 & 726 \\
\hline 8 & 14.00 & 33 & 43,6 & 80,2 & 42.1 & 602 \\
\hline 9 & 15.00 & 29 & 43,2 & 61,5 & 38.5 & 527 \\
\hline 10 & 16.00 & 27 & 38,5 & 50.7 & 36.9 & 379 \\
\hline 11 & 17.00 & 23 & 35,2 & 46,7 & 36.3 & 165 \\
\hline & & & & & TOTAL & 4341 \\
\hline
\end{tabular}

(Sumber: Hasil Pengamatan, 2017)

\section{ANALISIS DATA VOLUME AIR DESTILASI}

Berdasarkan data hasil pengamatan pada kondisi A dan Kondisi B yang diamati, besarnya volume air hasil pemurnian dengan ketebalan air baku didalam kotak penguap setebal $1 \mathrm{~cm}$ seperti yang disajikan pada Tabel 3 dan Gambar 6.

Tabel 3. Volume Air Berdasarkan Perlakuan untuk Ketebalan Air t=1 cm

\begin{tabular}{clc}
\hline No & \multicolumn{1}{c}{ Pengamatan } & $\begin{array}{c}\text { Volume Air Hasil } \\
\text { Pemurnian } \\
(\mathbf{m l})\end{array}$ \\
\hline 1 & $\begin{array}{l}\text { Kondisi A ( } \mathrm{t}=1 \text {; dengan cermin cekung \& } \\
\text { tanpa Wire Heater Aktif) }\end{array}$ & 1745 \\
\hline 2 & $\begin{array}{l}\text { Kondisi B ( } \mathrm{t}=1 ; \text { dengan cermin cekung \& } \\
\text { tanpa Wire Heater Aktif) }\end{array}$ & 4341 \\
\hline (Sumber: Hasil Pengamatan, 2017)
\end{tabular}

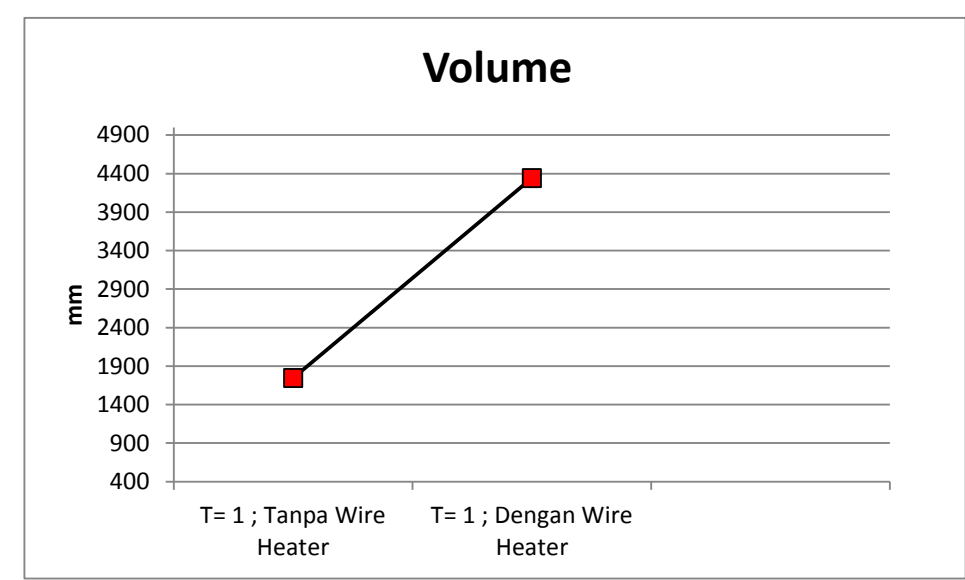

Gambar 6. Grafik Volume Air Dua Perlakuan dengan Tebal Air $1 \mathrm{~cm}$ 
Berdasarkan tabel dan gambar diatas, terjadi peningkatan volume air pemurnian yang dihasilkan dengan cukup significant, yaitu dari $1745 \mathrm{ml}$ menjadi $4341 \mathrm{ml}$, dengan kondisi pemanasan selama 10 jam. Peningkatan volume ini tentu saja merupakan hasil dari kinerja penambahan energi panas dari wire heater didalam kotak penguap. Hal ini sesuai dengan yang dinyatakan oleh Chaichan, M.T.,dan Kazem, H.A (2015) dalam manuscriptnya yang berjudul “Water Solar Distiller Productivity Enhancement Using Concentrating Solar Water Heater And Phase Change Material (PCM)", yaitu pengembangan alat destilasi tenaga surya ini dapat dilakukan dengan meningkatkat produksi panas pada kotak penguap dengan menggunakan komponen heat exchanger atau wire heater.

\section{KESIMPULAN}

Berdasarkan hasil penelitian yang dilakukan diperoleh kesimpulan sebagai berikut:

a. Rancang modifikasi water solar destiler dengan menambahkan wire heater berenergi panel surya, dapat meningkatkan volume air pemurnian yang dihasilkan.

b. Penambahan wire heater bertenaga panel surya pada kota penguap, mampu peningkatan volume air hasil pemurnian sebesar $248,78 \%$ dibandingkan dengan volume hasil pemurnian tanpa penambahan wire heater. Kondisi pengamatan dilakukan dalam jangka waktu 10 jam mulai dari pukul 07.00 sampai pukul 17.00 WIB, dengan ketebalan air di dalam kotak penguap setbal 1 $\mathrm{cm}$.

\section{DAFTAR PUSTAKA}

Chaichan, M.T., Kazem, H.A., (2014)., "Water Solar Distiller Productivity Enhancement Using Concentrating Solar Water Heater And Phase Change Material (PCM)".

Dewi, A.Y., Antonov. (2013)., "Pemanfaatan Energi Surya Sebagai Suplai Cadangan Pada Laboratorium Elektro Dasar Di Institut Teknologi Padang"., Jurnal Teknik Elektro Volume 2 No. 3 November 2013., p: 20-28

Xing J., Xu, C., Han, X., Xiaoze D., Wei, G., Yongping Y., (2017)., "A Review Of The Concentrated Photovoltaic/Thermal (Cpvt) Hybrid Solar Systems Based On The Spectral Beam Splitting Technology"., Applied Energy 187 (2017)., p : 534-563.

Zulkarnain, I., (2016)., "Rancang Alat Pemurni Air Laut Tenaga Surya Dengan Kolektor Panas Cermin Cekung dan Kotak Pengembun”., Laporan Penelitian Polinela., Lampung. 